Proc. Estonian Acad. Sci. Geol., 2006, 55, 3, 189-212

\title{
Impact-induced and diagenetic changes in minerals in the sandy ejecta of the Kärdla crater, NW Estonia
}

\author{
Anne Kleesment ${ }^{\mathrm{a}}$, Mare Konsa ${ }^{\mathrm{a}}$, Väino Puura ${ }^{\mathrm{b}}$, Juha Karhu ${ }^{\mathrm{c}}$, Ulla Preeden ${ }^{\mathrm{b}}$, \\ and Toivo Kallaste ${ }^{\mathrm{a}}$ \\ a Institute of Geology at Tallinn University of Technology, Estonia pst. 7, 10143 Tallinn, Estonia; \\ kleesmen@gi.ee, mare@gi.ee, kallaste@egk.ee \\ b Institute of Geology, University of Tartu, Vanemuise 46, 51014 Tartu, Estonia; vaino.puura@ut.ee, \\ ulla.preeden@ut.ee \\ c Department of Geology, Helsinki University, Gustaf Hällströmin katu 2a, FI-00014; \\ Juha.Karhu@helsinki.fi
}

Received 23 September 2005, in revised form 19 January 2006

\begin{abstract}
The sand-rich ejecta containing a considerable amount of mineral grains with impactinduced features was studied in five boreholes drilled around the Kärdla impact meteorite structure. Quartz grains with planar deformation features and planar fractures, as well as cracked grains showing lowered crystallinity by X-ray diffractometry, were recorded. The orientations of shock-produced deformation features, with the orientation planes $\{10 \overline{1} 3\}$ (dominating), $\{10 \overline{1} 1\},\{10 \overline{1} 2\}$, and $\{22 \overline{4} 1\}$, suggest the peak pressure of 10-25 GPa. The ejecta deposits of the annular zone 2-5 km outside the crater rim yield specific quartz grains surrounded by $\mathrm{C}$-rich amorphous material. The carbon isotope composition of the particles reminds of that of the Early Ordovician Dictyonema shale, the uppermost part of the target, but also coincides with the general cosmic (meteorite) carbon isotope composition. The ejected detrital minerals, mostly quartz, are often coated with transparent or semitransparent yellowish and dark pyrite-bearing apatite, which is probably of post-impact origin, preceding or partly simultaneous with diagenetic carbonate cementation. Unlike carbon coatings on quartz, known from the Lappajärvi crater, the apatite coatings have not been described anywhere in impact craters. Carbon-rich coatings and particles, and apatite coatings have not been previously found in the Estonian bedrock.
\end{abstract}

Key words: impact craters, ejecta, shock metamorphism, C-rich particles, stable carbon isotopes, diagenesis, Kärdla crater.

\section{INTRODUCTION}

The Kärdla crater on Hiiumaa Island, NW Estonia, is a well-preserved $4 \mathrm{~km}$ wide and $500 \mathrm{~m}$ deep Late Ordovician (455 Ma) complex impact structure (Puura \& Suuroja 1992; Ainsaar et al. 2002; Suuroja et al. 2002; Puura et al. 2004), 
which formed in the shallow shelf sea area. The target section consists of the Palaeozoic sedimentary pile and Palaeoproterozoic crystalline basement. At the stage of transient cavity the target was possibly penetrated as deep as about $800 \mathrm{~m}$ (Puura et al. 2004). At the early post-impact stage, the elevated structural elements like the crater rim wall and surrounding structurally uplifted area were subjected to marine and possibly sub-aerial erosion. Later on, due to the sea transgression, the eroded surface was buried under thin (20-300 m) post-impact, Upper Ordovician carbonate deposits and, possibly, subsequent suites destroyed through erosion (Puura \& Suuroja 1992; Ainsaar et al. 2002). The sandy ejecta deposit under study has a transitional position between the coarse-grained, mainly carbonate breccia layer and debris-rich carbonate layers of the post-impact cover (Ainsaar et al. 2002).

The numerous drill cores from the surroundings of the Kärdla crater have revealed a regular annular area with sandy ejecta deposits (Fig. 1). Puura \& Suuroja (1992) and Ainsaar et al. (2002) found that, in places, the sandy ejecta

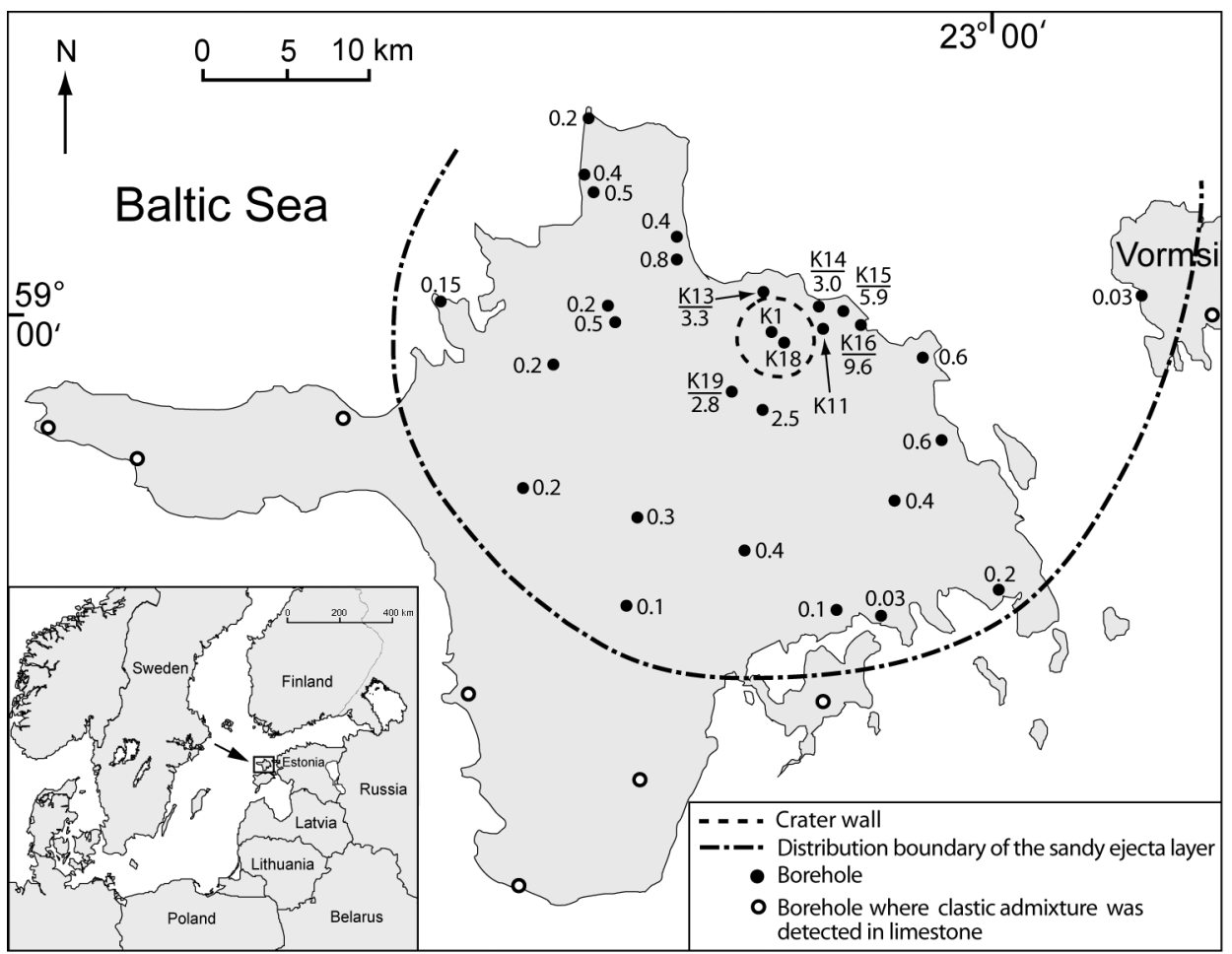

Fig. 1. The distribution of the sandy ejecta layer in the vicinity of the Kärdla crater and schematic location of drilling sites. K13, K14, K15, K16, and K19 indicate the numbers of the studied cores, and blank numbers - the thickness of the sandy ejecta layer in metres. For the studied cores thickness is shown under the core number. 
blanket is divided into two different parts. The lower poorly sorted part is of primary impact origin. The upper more sorted and layered part consists of similar material derived from the primary ejecta and rim wall. The upper layer deposited in marine conditions. Kleesment et al. (1987) described the mineral composition and grain size distribution of these deposits. Puura et al. (2004) reported occasional quartz grains with impact-induced planar fractures (PFs) and planar deformation features (PDFs) in a mass of unshocked grains of the ejecta deposits. A variety of $\mathrm{C}$-rich and magnetic particles, shocked quartz grains, and detrital minerals, including phosphate fragments of brachiopod fossils with dark coatings, have been observed in the ejecta (Puura et al. 1997, 2000b, 2002).

Many publications (e.g. Reimold et al. 1994; Stöffler \& Langenhorst 1994; Koeberl et al. 1996; McCarville \& Crossey 1996; French et al. 1997) describe the impact-caused deformations and transformations of minerals from the interiors of meteorite structures. Compared to the interior, mineralogy of the ejected debris is much less studied. Grieve et al. (1996) and Deutsch et al. (2000) documented minerals with planar microstructures in the ejecta of the Popigai structure. The ejecta deposit may contain impact diamonds (in Popigai; Deutsch et al. 2000) or be enriched with shocked quartz with elevated C and Ir contents (Permian-Triassic boundary sections in the Antarctic and Australia; Retallack et al. 1998). Langenhorst et al. (1999) described grains with amorphous carbon coatings in the allochthonous breccia of the Lappajärvi impact crater. Isbell et al. (1999) reported rare quartz grains floating on black coaly material in ejecta deposits.

Puura et al. (2004) localized the impact breccia units with PDF-quartz and K-enriched compositions in the interior of the Kärdla crater. The PDFs were found in well-rounded grains within the predominantly crystalline-derived allochthonous breccia units. Here considerably rare rounded PDF-quartz most probably originates from the sedimentary cover. In the sandy ejecta, similar rounded PDF-quartz is even more abundant.

Ainsaar et al. (2002) studied the material derived from the elevated parts of the crater structure into the post-impact sediments within and around the structure, including the sandy ejecta. Versh et al. (2005) described the paragenetic sequence of mineralization and characterized the thermal conditions of the formation of different authigenic minerals in the crater interior. Jõeleht et al. (2005) modelled the possible impact-induced hydrothermal system at Kärdla. As seen from that model, the sandy ejecta localized in the area of infiltration of surface waters, thus outside the reach of hydrotherms.

The present study deals with impact-related features of the sandy ejecta deposit of the Kärdla crater. Shock-pressure effects of detrital minerals are described. Specific carbon-rich material is reported and its isotope composition interpreted. Post-impact alterations, including phosphate, sulphide, and carbonate phases in coatings on mineral grains, are determined. 


\section{GEOLOGICAL SETTING AND COMPOSITION OF THE SANDY EJECTA LAYER}

The Kärdla impact crater formed in the shallow epicontinental sea (Puura \& Suuroja 1992; Ainsaar et al. 2002; Puura et al. 2004). The target was composed of the stratified sedimentary cover comprising (from the top) bedded Upper and Middle Ordovician limestone (up to $20 \mathrm{~m}$ thick), Lower Ordovician Dictyonema shale (argillite with an admixture of organic matter, about $2 \mathrm{~m}$ thick), and an up to $200 \mathrm{~m}$ thick layer of Lower Ordovician to uppermost Vendian sand, silt, and some clay, which covered the Precambrian basement consisting of granites, gneisses, amphibolites, and other crystalline rocks. The impact caused excavation of both sedimentary and crystalline parts of the target. Poorly lithified Cambrian and Lower Ordovician sands, silts, and clays became a major source of loose material for the ejecta. This fine-grained material is composed of mineral grains with distinct impact-metamorphic signatures (quartz with PDFs and PFs) and grains less influenced (cracked) by the impact among much more abundant intact grains.

The sandy ejecta (up to $9.6 \mathrm{~m}$ thick, see Fig. 1) surrounds the crater within a radius of $20 \mathrm{~km}$ (Puura \& Suuroja 1992; Suuroja et al. 2002; Fig. 1) and rests mainly on the up to $16 \mathrm{~m}$ thick breccia composed of Ordovician carbonate rocks mixed with a minor portion of crystalline fragments and Ordovician and Cambrian sandy material in cement. Only in core K13 (Fig. 1), nearest to the crater rim wall, it lies directly on deformed Cambrian sandstone layers. The ejecta consists of fragmented and disintegrated Cambrian and Lower Ordovician sand, silt, and clay, with a minor admixture of fragments from all the other lithological units of the target. It is the thickest and best observed in cores drilled at a distance of 4-7 km NE of the crater centre (K14, K15, K16; Fig. 2). In the proximal zone of the blanket (2-4 km from the centre; K11), the ejecta was eroded before the formation of the covering Upper Ordovician carbonate beds (Haljala, Keila, and subsequent formations; see Fig. 2). After the impact, the sand deposition was gradually subdued by carbonate sedimentation (Ainsaar et al. 2002). An anomalously abundant admixture of quartz, other siliciclastic and clay minerals, derived from the crater ejecta and wall structures, occurs upwards in the Ordovician carbonate sequence through some $20 \mathrm{~m}$. It corresponds to a sedimentation history of about $10 \mathrm{Ma}$ (Ainsaar et al. 2002).

The present research is a continuation of the general lithological study by Kleesment et al. (1987). Mainly the same sample collection was used here (Table 1; Fig. 1). The deposit is mostly composed of fine-grained sandstone with predominating grain size of $0.25-0.1 \mathrm{~mm}$, interbedded with very fine 


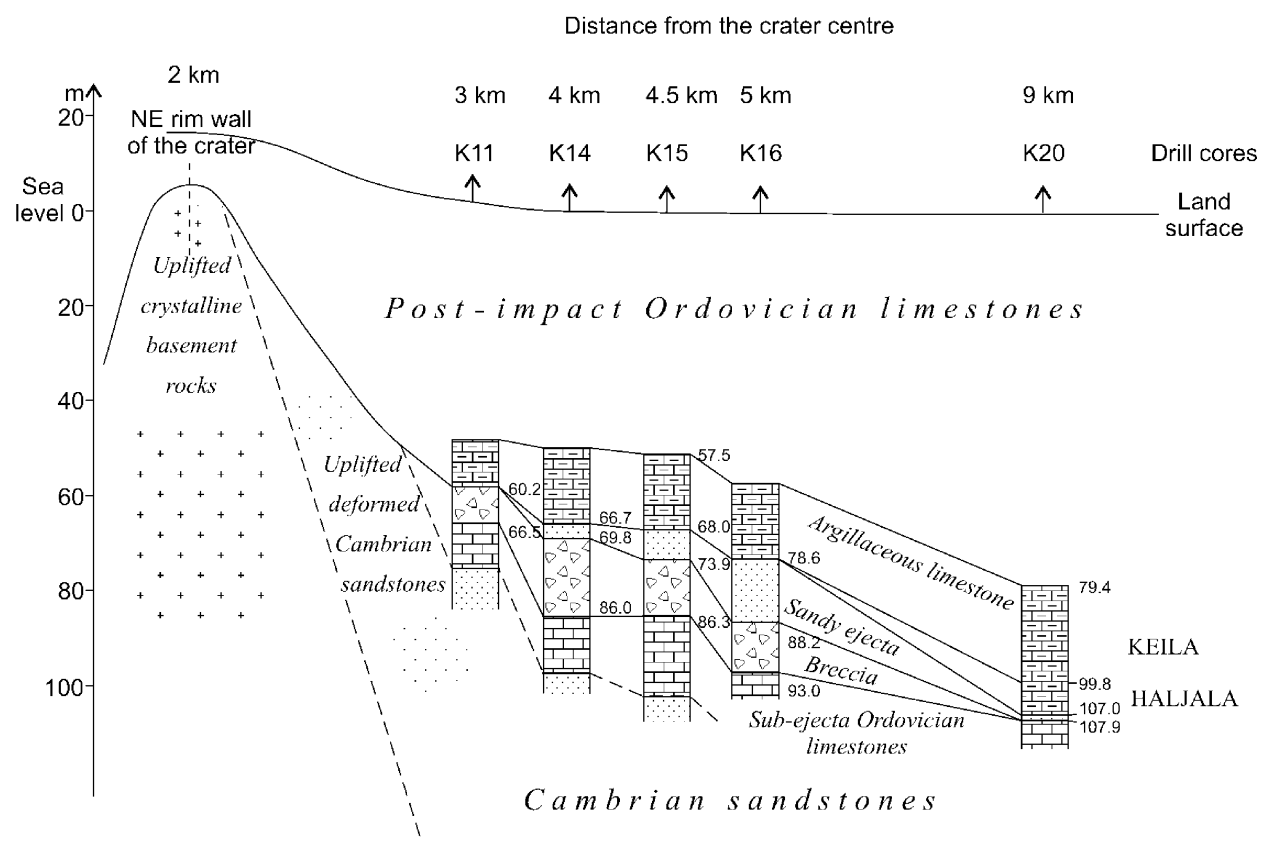

Fig. 2. Distribution of the sandy ejecta layer NE of the crater. For location of drill cores see Fig. 1. For depths of the investigated samples see Table 1.

$(0.1-0.063 \mathrm{~mm})$ and medium-grained $(0.5-0.25 \mathrm{~mm})$ sandstone. Rounded to subrounded quartz grains dominate in the detrital part of the sandstones. Feldspar is mainly orthoclase (Kleesment et al. 1987). Fine-grained sandstones are poorly to moderately sorted, but of "mature" composition. Quartz and zircon dominate among light and heavy minerals, respectively. The mineral composition, grain size, and roundness suggest that the finer material is a mixture of Cambrian and Lower Ordovician sandstones. In coarser fractions, fragments of crystalline and sedimentary rocks are found in variable proportions. The coarser fraction contains phosphatic brachiopod fragments derived from the Upper Cambrian to Lower Ordovician phosphate-bearing beds. The lowermost part of the sandy ejecta includes conglomeratic sandstone interlayers with pebbles of black Dictyonema shale (kerogen-enriched argillite) and crystalline rocks (Kleesment et al. 1987).

The ejecta deposit is well cemented. The cement is mostly calcitic with dolomite admixture (Kleesment et al. 1987) and contains also tiny, sparsely distributed, authigenic pyrite crystals. In the middle part of the deposit, in sections K15 and K16 (Fig. 1; Table 1), some dolomite crystals have an expanded lattice. The content of cement is up to $10-30 \%$ of the rock. 


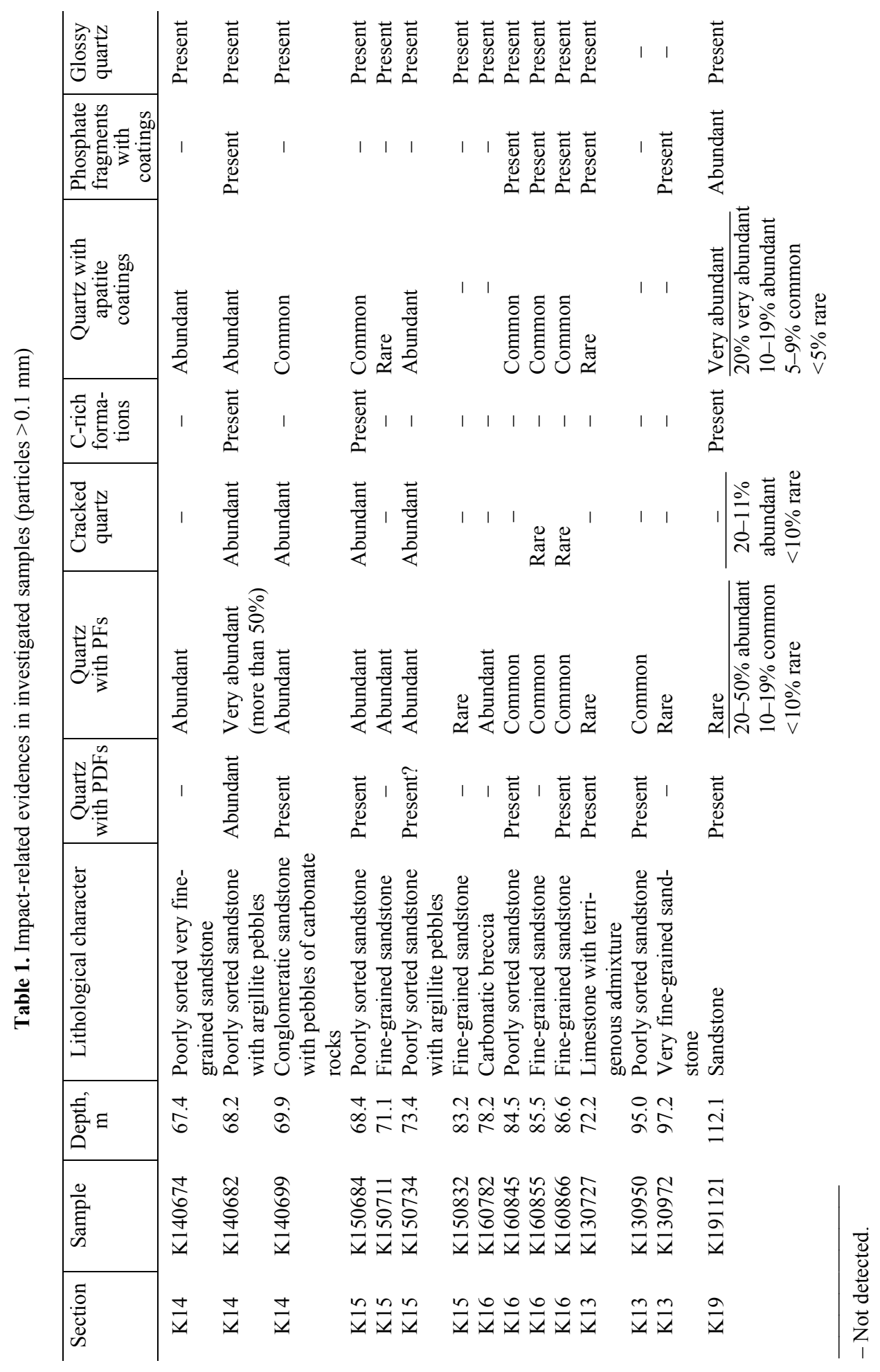




\section{MATERIAL AND METHODS}

A total of 14 samples, $100-500 \mathrm{~g}$ each, taken from the sandy ejecta layer of five cores (K13-K16 and K19), were investigated (Figs 1, 2; Table 1). The grain size fractions of $>1,1-0.5,0.5-0.25,0.25-0.1,0.1-0.05$, and $0.05-0.01 \mathrm{~mm}$ were separated and examined in transmitted and reflected light under binocular (BM) and petrographic (PM) microscopes. The fractions coarser than $0.1 \mathrm{~mm}$ were divided into the magnetic and non-magnetic portions, which were both observed under the BM to determine the character and surface of the grains. The fraction $0.1-0.05 \mathrm{~mm}$ was studied in immersion under the PM in plane- and cross-polarized light. The composition and character of mineral grains and their relations with cement were observed in thin sections under the PM. Crushed quartz grains were examined for crystallinity in the X-ray diffractometry (XRD) laboratory, Institute of Geology at Tallinn University of Technology (IG TUT). Major components were analysed from fused Li tetraborate discs and pressed-powder pellets in the $\mathrm{X}$-ray fluorescence laboratory of the IG TUT.

The orientations of PDFs in quartz grains were studied in thin sections under the PM following standard petrofabric procedures and measured using standard universal stage (U-stage) techniques (see French 1998) at the Institute of Geology, University of Tartu (IG UT). The orientation of the pole to each set of PDFs and orientation of the $c$-axis of the quartz grains were measured. The data are plotted on a standard stereonet, and the results are expressed as the location of the pole to the PDFs relative to the $c$-axis.

Mineral grain surfaces of samples were examined under the scanning electron microscope. The elemental composition of coatings and appendages on grain surfaces were determined in thin sections and on separate grains using the energy dispersive spectrum (EDS) analyser Link analytical AN-10000 in the laboratory of the Centre of Materials Technology at TUT. The study was supported by the results of $\mathrm{HCl}$ dissolution of particles, and by XRD data obtained in the IG TUT.

To study the composition of the organic matter in mineral grain coatings, elemental CHN analysis was performed in the laboratory at the IG UT using the Perkin-Elmer 2400 Series II elemental analyser.

In order to understand the origin of carbon fixed in coatings, a comparative isotopic study of non-carbonate forms of this element fixed in the impact breccia samples was carried out. The material from the sandy ejecta layer was taken from sandstone of core K19 (depth $112.1 \mathrm{~m}$, sample K191121). Quartz grains with dark coatings and appendages were picked out of the grain size interval $0.5-0.1 \mathrm{~mm}$ of this sample (K191121-O1 and K191121-O2, respectively). Samples of allochthonous crystalline-derived breccia matrix of the crater interior were taken from cores K1 (depth $373.7 \mathrm{~m}$, sample K13737) and K18 (depth $383.0 \mathrm{~m}$, sample K183830). Magnetic particles were separated from the breccia matrix of core K18 (depth 398.4 m, sample K183984M1). For reference, samples of Dictyonema shale and Ordovician limestone of the Uhaku Stage were taken 
from core K31 drilled $14 \mathrm{~km} \mathrm{NW}$ of the crater centre (samples K31/7-4 and $\mathrm{K} 31 / 60$, depths 80.0 and $69.0 \mathrm{~m}$, respectively). Carbon isotopes were studied in the Isotope Laboratory at the Geological Survey of Finland. For the analysis of the isotopic composition of organic carbon any carbonate present in the samples was dissolved using concentrated $\mathrm{HCl}$ at $60^{\circ} \mathrm{C}$. The remaining organic carbon was oxidized to $\mathrm{CO}_{2}$ by $\mathrm{CuO}$ in sealed quartz tubes at $950^{\circ} \mathrm{C}$, purified in a vacuum line, and analysed using a Finnigan MAT 251 mass spectrometer. The size of a blank sample was $0.23 \mu \mathrm{mol}$, amounting to $14 \%$ of the quantity of the smallest samples. No blank corrections were applied to the data. For the analysis of the isotopic composition of calcite, the samples were reacted with anhydrous phosphoric acid at $25^{\circ} \mathrm{C}$, and the resulting $\mathrm{CO}_{2}$ was measured for carbon and oxygen isotopes.

\section{RESULTS}

\section{Shock-pressure effects}

Cracked, irregular, and splinter-shaped garnet grains, similar to the findings from allochthonous breccias inside the crater (Konsa et al. 2000), were recorded in most samples of the sandy ejecta layer. All samples revealed PDFs, and especially PFs (Table 1). Quartz grains with PDFs are most frequent (in 1-2\% of grains) in the lower parts of the layer in cores K14 (particularly in sample K140682), K15, and K16, but also in the upper part of the layer in K15 (sample K150684). Grains with PFs are more abundant, accounting to $50 \%$ of the grains studied from cores K14 and K15 (Table 1). The lamellae of PDFs are closely spaced, $0.5-5 \mu \mathrm{m}$ apart, and form one to three lamellae systems. Planar features are relatively widely spaced (5-20 $\mu \mathrm{m}$ apart). The PDF- and PF-containing grains are commonly transparent, relatively coarse, and mainly well-rounded, but subrounded grains were also found (Fig. 3). Orientations of PDFs are crystallographically controlled and show a
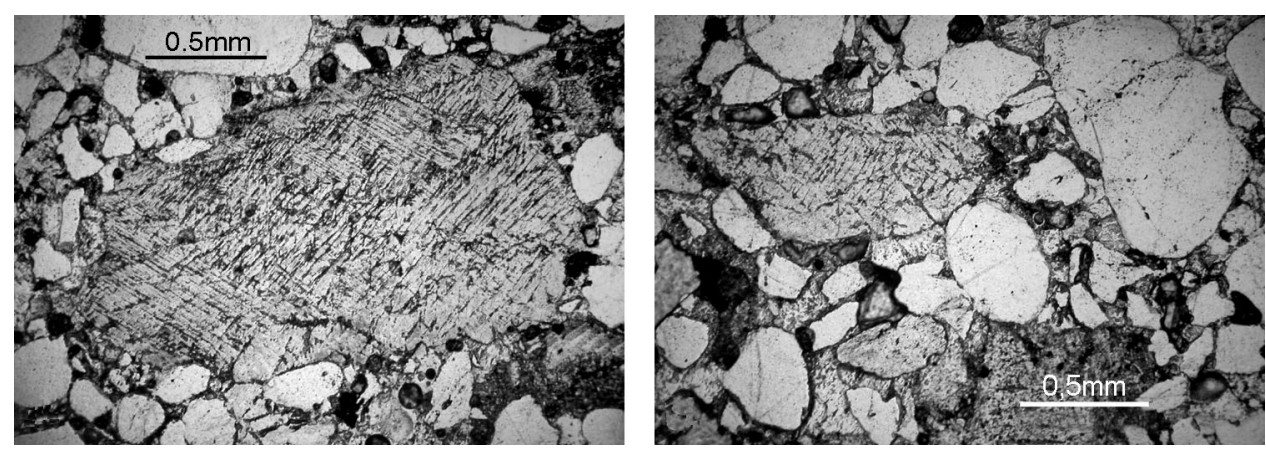

Fig. 3. Thin section micrographs showing quartz grains with a visible two-directional set of PDFs. Plane-polarized light, sample K140682. 
pressure-dependent variation. According to the analysis of 22 sets of 5 thin sections of samples K140682, K140699, K160855, and K191121, the dominating orientation plane is $\{10 \overline{1} 3\}$, but also directions $\{10 \overline{1} 1\},\{10 \overline{1} 2\}$, and $\{22 \overline{4} 1\}$, were determined (Fig. 4).

Specific cracked quartz grains were found in cores K14 and K15, rarely also in core K16 (Table 1). These are milky under the BM (Fig. 5A,B), and cloudy and yellowish under the PM. Such a fracturing is typical of rounded grains with a diameter of $0.25-0.5 \mathrm{~mm}$, occasionally observed in the grain size range of $0.25-0.1 \mathrm{~mm}$, and is absent in grains less than $0.1 \mathrm{~mm}$ in diameter. Commonly, fractures in quartz grains are spaced irregularly and sometimes more than one system of fractures are present. The surface of a cracked grain has an extremely high relief (Fig. 6A,C). Higher magnifications reveal an intricate system of irregularly spaced fractures (Fig. 6B,D). X-ray diffractometry of three peaks $(104,220$, and 302) of cracked quartz grains shows broadening of the peaks by $20 \%$, suggesting somewhat lowered crystallinity (Fig. 7).

Cracked quartz grains with low crystallinity occur on few levels, being most abundant (more than $20 \%$ of the studied grains) in the middle part of the sandy ejecta layer in cores K14 (samples K140682 and K140699) and K15 (samples K150684 and K150734). A few cracked quartz grains with low crystallinity $(<10 \%)$ were found in the lower part of core K16 (samples K160855 and K160866; Table 1). In the crater interior, cracked quartz grains are abundant in allochthonous breccia, accounting to even more than $20 \%$ of the volume. In samples from the deep sub-crater basement they account to less than $5 \%$ of the grains, which is usual for the basement rocks far from the crater (Puura et al. 2000a). Irregular cracking is always observed in grains over $0.1 \mathrm{~mm}$ in size, especially in grains coarser than $0.5 \mathrm{~mm}$.

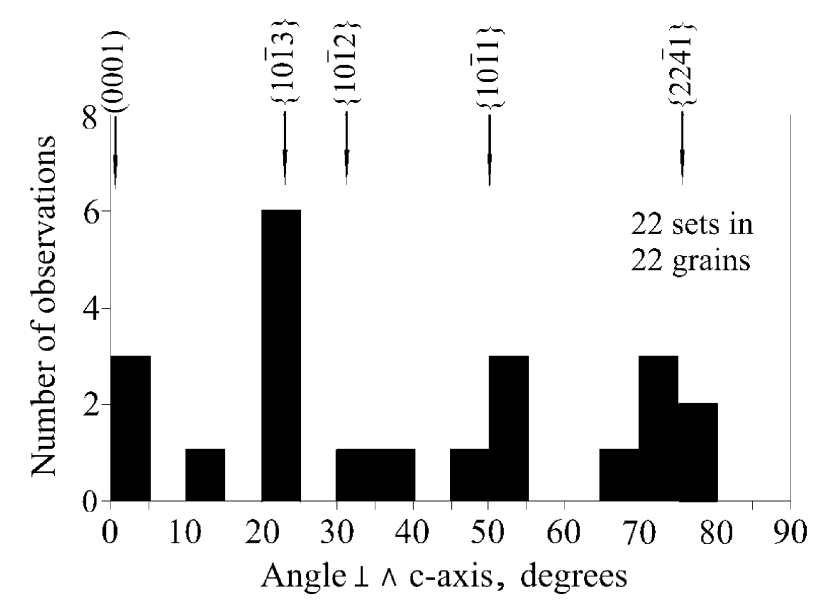

Fig. 4. Histogram of orientations of PDFs in quartz grains in thin sections of samples K140682, K140699, K160855, and K191121. 

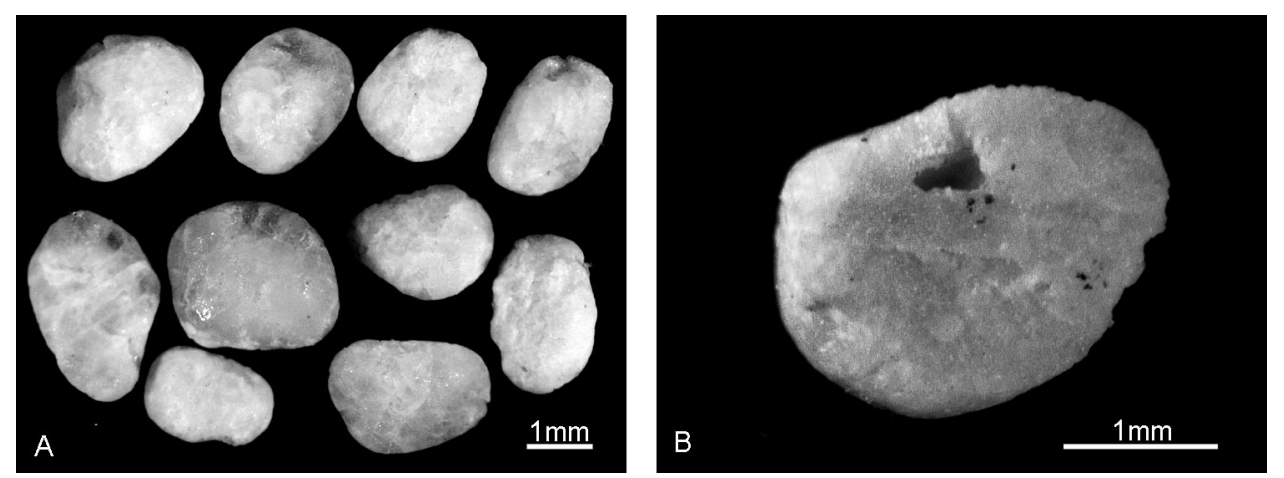

Fig. 5. Cracked quartz grains under binocular microscope. (A) Sample K150734; (B) sample K150734.
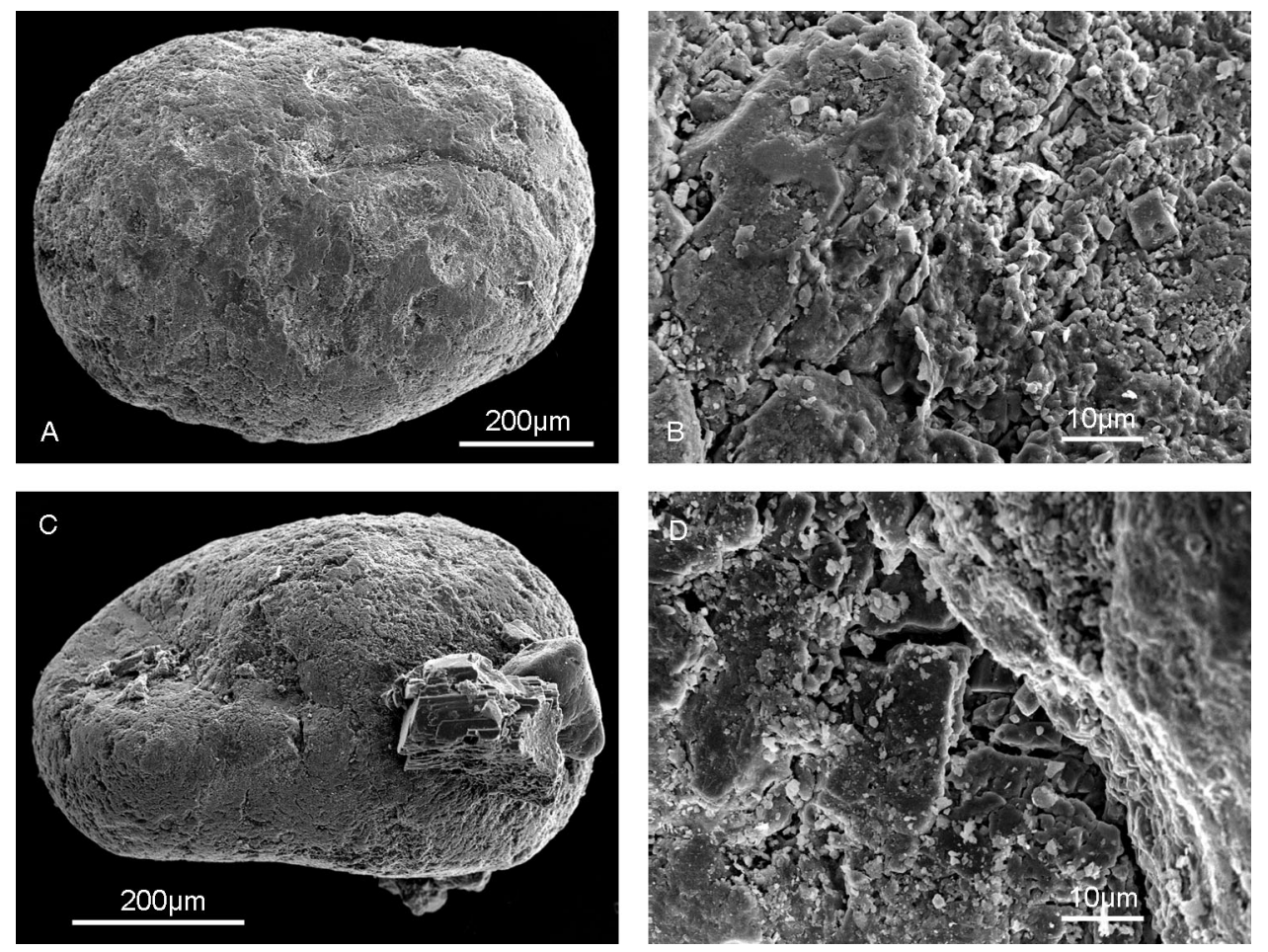

Fig. 6. SEM photographs of cracked quartz grains showing high surface relief with broken block features. Under higher magnifications, (B) and (D), intricate fracture sets are observed. (A), (B) Sample K140682; (C), (D) sample K160866. 


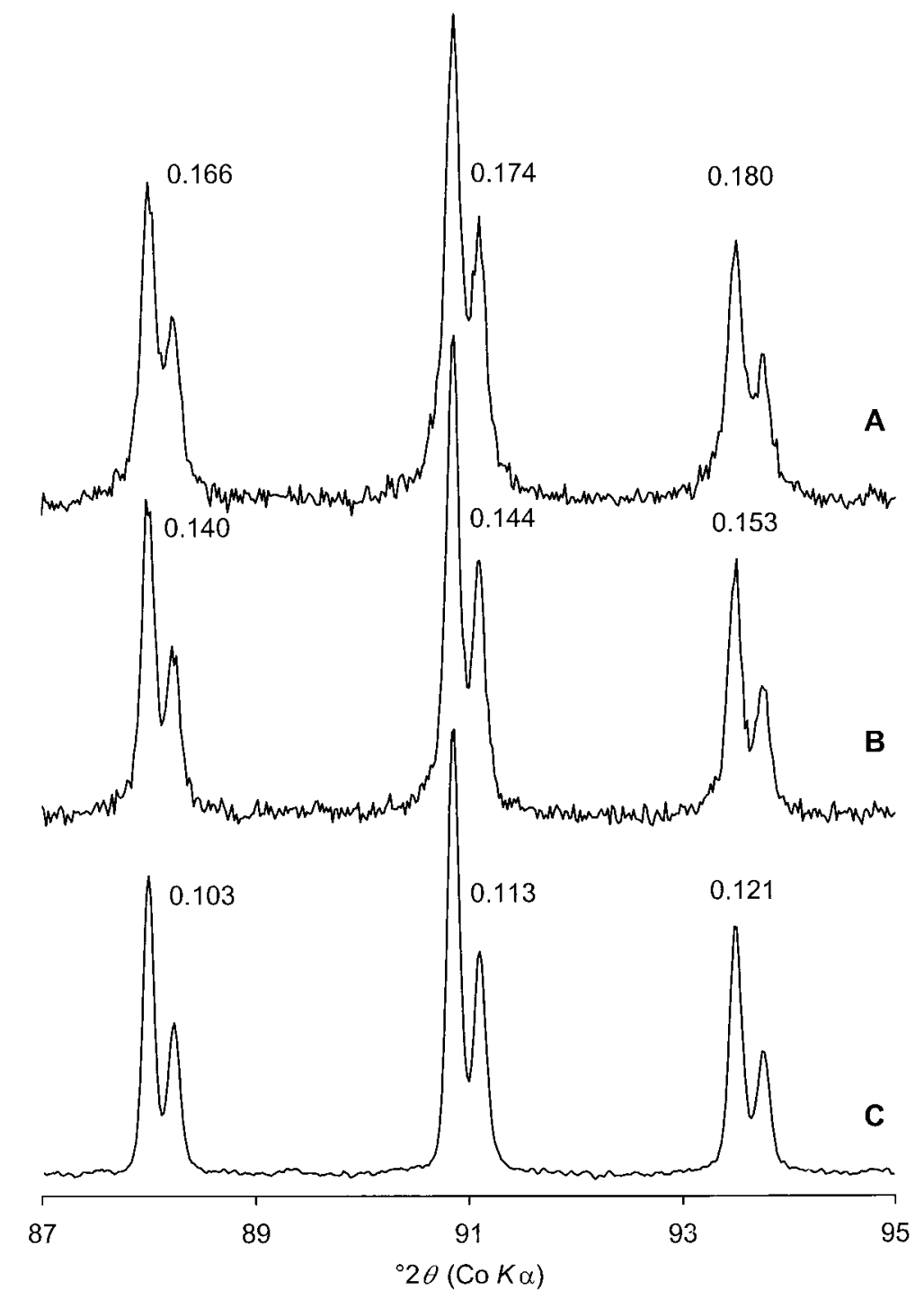

Fig. 7. X-ray diffractograms of quartz reflections 104, 302, and 220 showing transformation of crystallinity. The number near the peak shows width $\left({ }^{\circ} 2 \theta\right)$. (A) Cracked quartz, K140682. (B) Estonian reference quartz from Devonian sandstone. (C) Quartz from pegmatite as reference of ideal crystallinity.

The characteristics of quartz grains in sediments of Estonia and the surrounding region have been discussed also in earlier publications (Konsa 1989; Kleesment 1998). The above-described association of cracked quartz grains and grains with PFs and PDFs have been found neither in the sedimentary cover nor in the crystalline basement of Estonia. 


\section{Apatite coatings on mineral grains}

Yellowish, brown or black coatings cover mineral grains, especially quartz, completely or partly (Figs 8-11). Various kinds of such grains were found in sample K191121, where more than $50 \%$ of quartz grains had coatings (Fig. 8A-D). The coating thickness is commonly $5-10 \mu \mathrm{m}$, in some cases up to $50 \mu \mathrm{m}$. The thickness often varies even in a single grain (Fig. 11A). The coatings are transparent, semitransparent or opaque (Fig. 8C,D). Compared to naked quartz grains, the outer surface of coated grains is remarkably smooth. The coating may be discontinuous, exposing spots of the naked grain surface (Fig. 9A-C). Some of the coated quartz grains have PDFs. The coatings on quartz may show concentric laminations (Fig. 11B): in places the $5-10 \mu \mathrm{m}$ thick yellowish rim is covered with a $2-3 \mu \mathrm{m}$ black or brown film. Numerous phosphatic fossil fragments scattered in the samples are mainly cloudy, containing fine pyrite crystals, and surrounded by a transparent or dark apatite rim (Figs 8C and 9D). In addition to quartz, some feldspars, garnet, apatite, and other detrital grains have similar coatings.
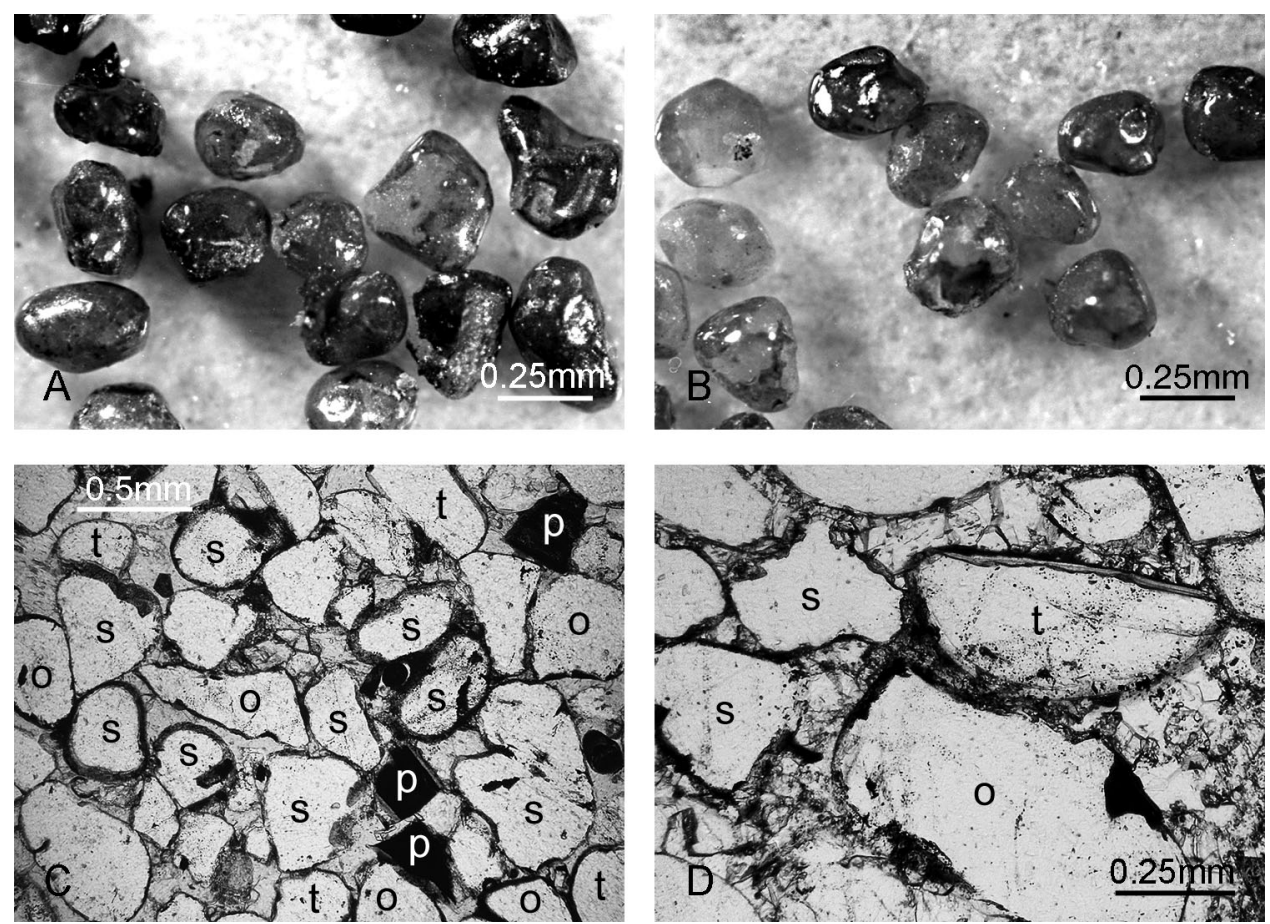

Fig. 8. (A), (B) Grains with dark coatings. (C), (D) Thin section micrographs showing coated grains in the rock. Grains with transparent $-t$, semitransparent $-s$, and opaque - o coatings are present. Three cloudy phosphatic fossil fragments (p) are seen, two with semitransparent coatings. Thin section photos in plane-polarized light. Sample K191121. 

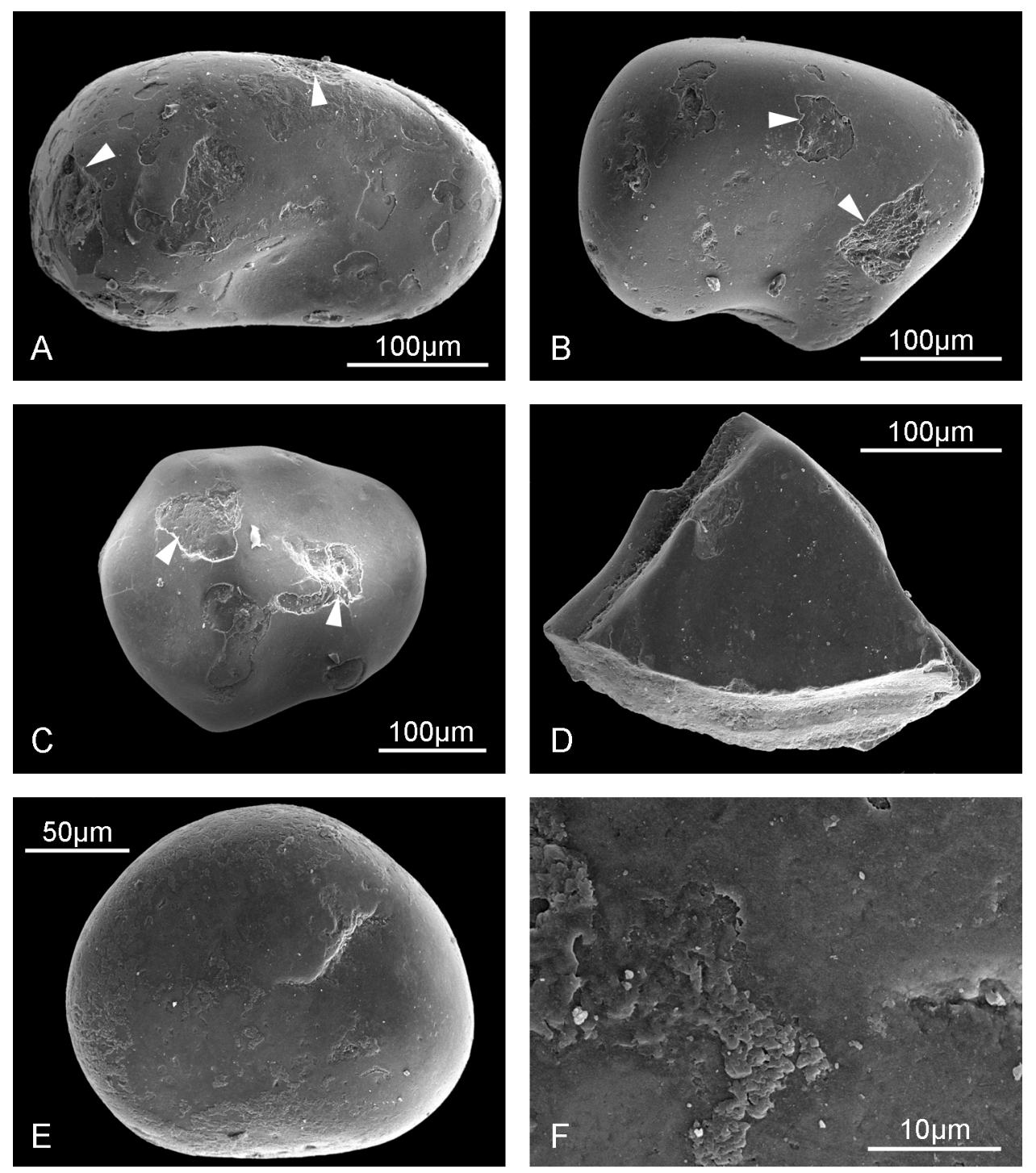

Fig. 9. SEM photographs of coated grains showing the smooth surface of grains. (A)-(C) Quartz grains with a smooth surface. The normal rough and pitted surface is observable only in spots indicated by arrows. (D) Phosphatic fossil fragment with dark coating. (E) Glossy quartz grain. (F) Detail of photo (E) with greater magnification. (A), (B), (D) Sample K160866; (C), (E), (F) sample K140682.

The SEM-EDS analysis shows that the coatings consist of apatite (Fig. 10). In addition, opaque black coatings contain abundant tiny pyrite crystals (Fig. 11A). The coatings are soluble in $10 \% \mathrm{HCl}$. After dissolution of the coating, the surface 

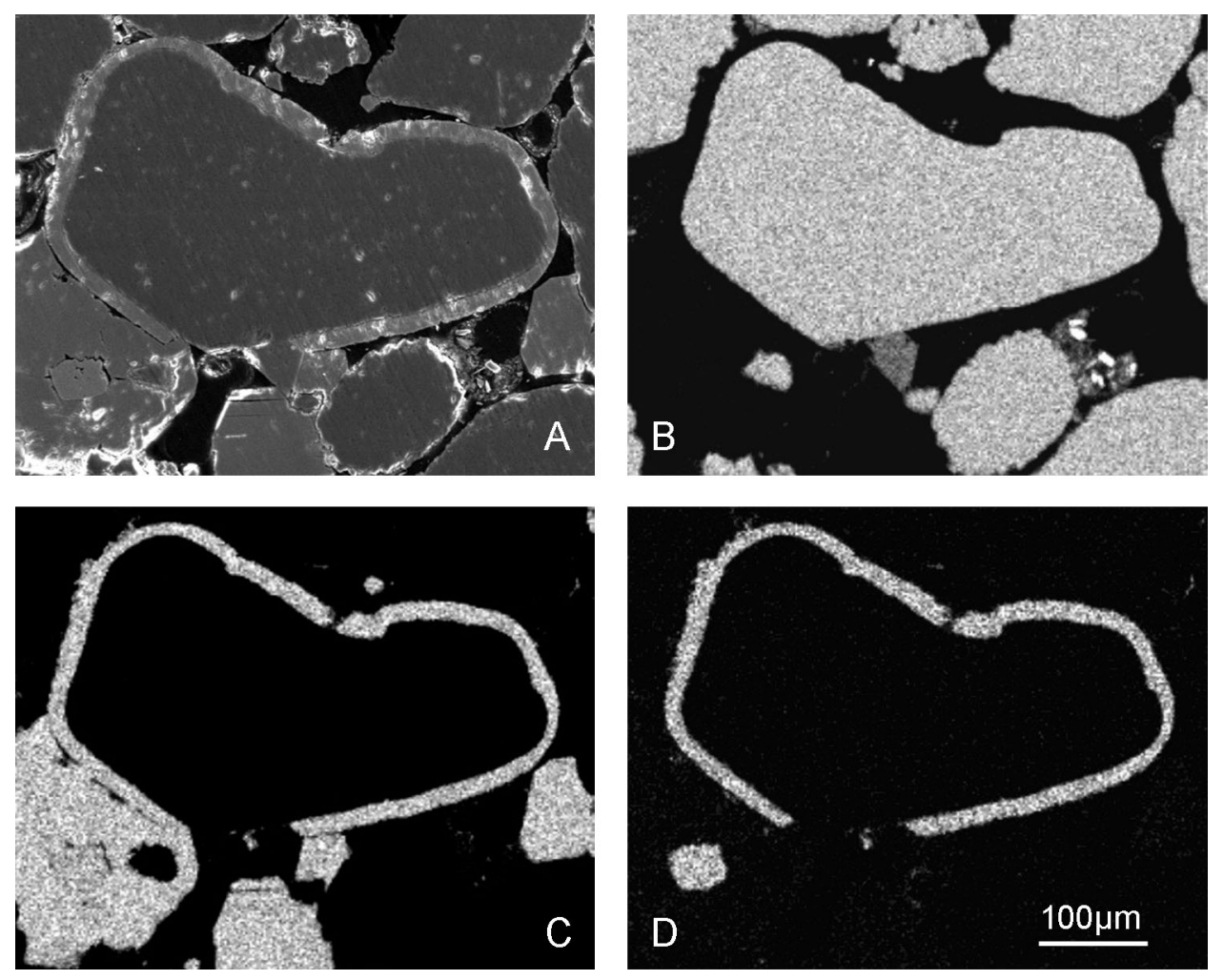

Fig. 10. (A) Area of the thin section with a coated quartz grain, SEM. (B)-(D) SEM/EDS Link analyser maps for Si (B), Ca (C), and P (D) of the thin section area in (A). Sample K191121.

of grains is uneven, corroded, as in detrital quartz of sedimentary rocks (Krinsley \& Doornkamp 1973; Hodel et al. 1988; Mahaney 2002; Fig. 11C,D). Although coated detrital grains occurred in all investigated core sections (Table 1), they were the most numerous in the sandy ejecta of core K19, where the content of phosphatic fossil fragments is the highest.

Apart from the coated quartz grains, almost all investigated samples contain $1-5 \%$ glossy quartz grains with a lustrous yellowish surface (Table 1). Under SEM, the surface of these grains is relatively smooth (Fig. 9E,F), but similarly to the coated grains described above, treatment with $10 \% \mathrm{HCl}$ exposed a characteristic high relief. Therefore, we assume that also glossy grains have an apatite coating, visible under optical microscope as an $\sim 1 \mu \mathrm{m}$ thick yellowish cover. Due to small thickness, the elemental composition of this coating could not be determined by microanalyser. The apatite coatings were probably formed during middle and late diagenesis, before and during carbonate cementation. In some cases, dark coatings are found on the cleavage surfaces of calcite that forms the diagenetic cement of rocks. 

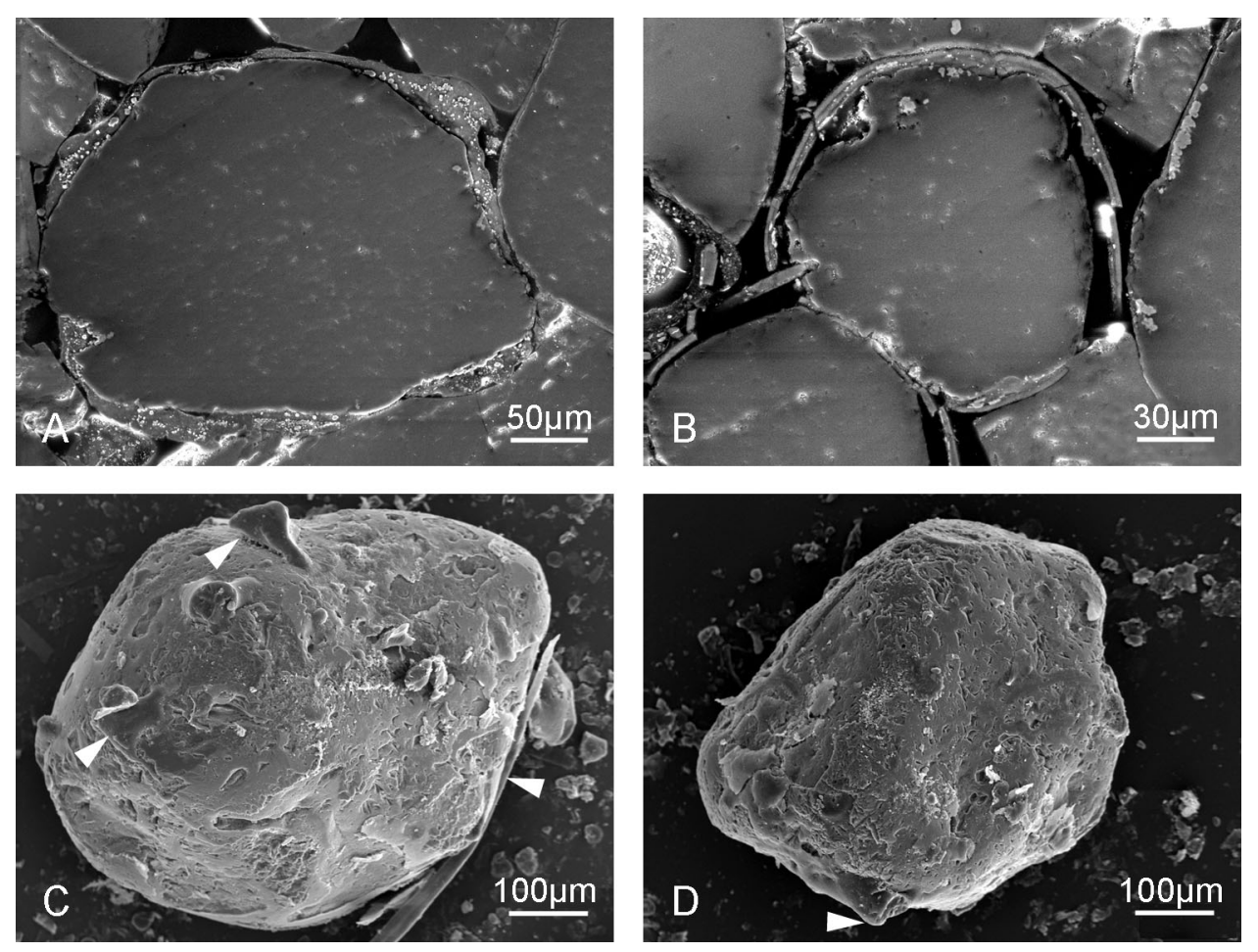

Fig. 11. SEM photographs. (A) Quartz grain with an opaque apatite coating. Abundant tiny pyrite crystals (white spots) are embedded within the apatite matrix. (B) Quartz grains with a stratified apatite coating. (C), (D) Apatite-coated quartz grains after dissolution in HCL showing a deeply etched surface. Arrows indicate black C-rich appendixes preserved after dissolution on the grain surface. (A), (B) Thin section, sample K191121; (C) sample K140682; (D) sample K150684.

\section{Carbon-rich material connected with quartz grains}

Three samples, K140682, K150684, and K191121, contained specific C-rich material (Table 1). The first time $\mathrm{C}$-rich coatings and appendages were determined in 2000 under a low-vacuum scanning electron microscope (ESEM) in the laboratory of the Department of Geology and Geochemistry of Stockholm University. C-rich material is represented by intricate overgrowths or hookshaped formations surrounding the quartz grains (Fig. 12A). Often the C-rich material forms drops, hollow bubbles, appendages or worm-like branches and complicated forms on the grain surface (Figs 12B,D, 13C,D). Mineral grains may be floating in black amorphous C-rich material (Fig. 13A,B) or be cemented with it (Fig. 12C). Scanning electron microscopy shows that the C-rich mass is porous (Fig. 13A-C,E,F), sometimes with authigenic crystals of feldspar in pores (Fig. 13F). According to SEM-EDS study, C-rich coatings and appendages contain no elements heavier than $\mathrm{Na}$. 

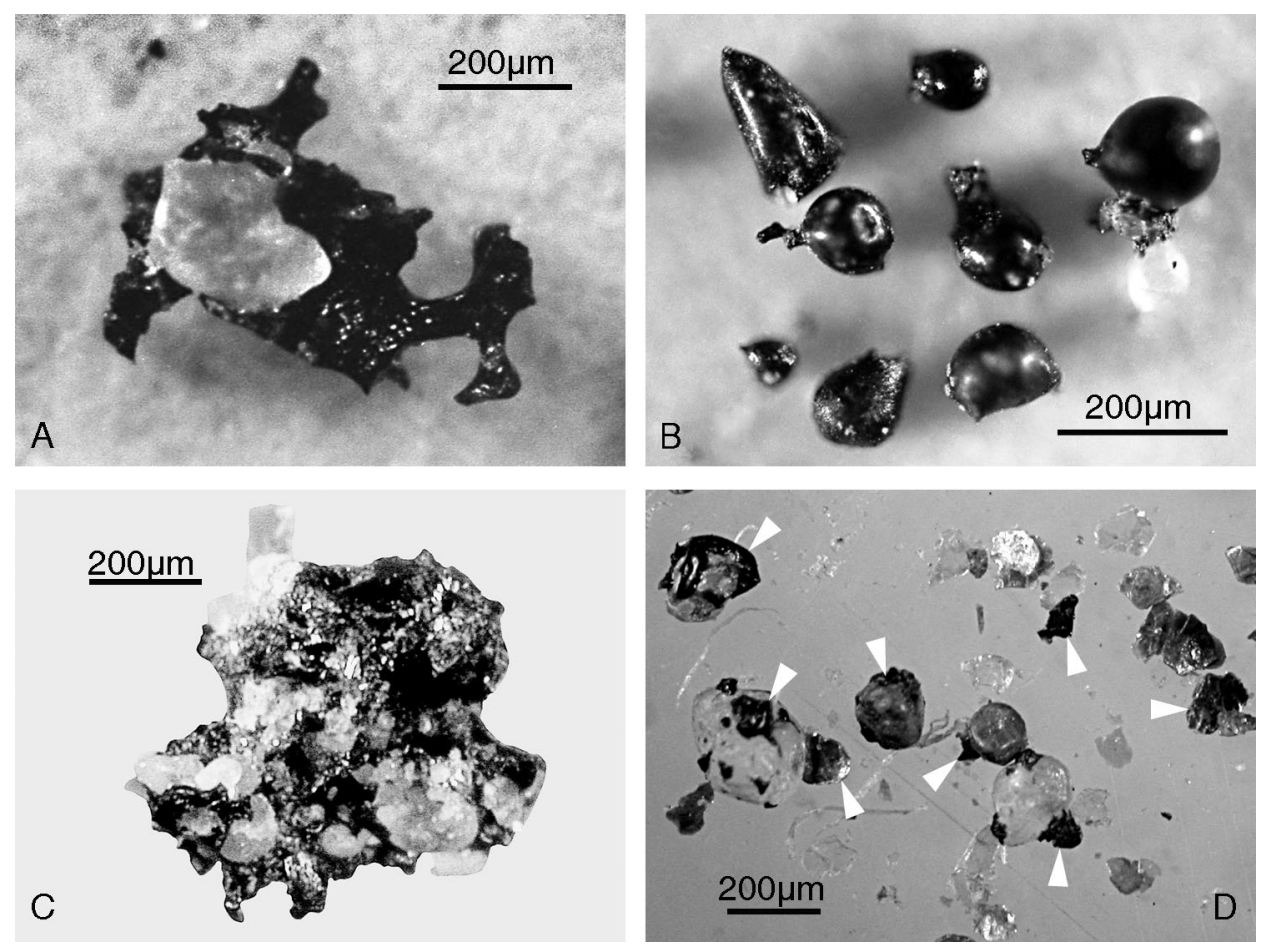

Fig. 12. (A) Quartz grain surrounded by a hooked C-rich coating, sample K150684. (B) C-rich hollow bubbles with branching appendages, sample K140682. (C) Quartz aggregate, cemented with C-rich matrix, sample K140682. (D) Coated quartz grains after solution in HCl. Survived C-rich appendages are indicated by arrows. Sample K150684.

Carbon-rich material is insoluble in $10 \% \mathrm{HCl}$ (Fig. 12C,D). X-ray diffractometry of this material showed no crystalline phases. By examining grains with $\mathrm{C}$-rich formations with the CHN analyser substantial amounts of $\mathrm{C}$ with very low concentrations of $\mathrm{H}$ and $\mathrm{N}$ were determined. This leads to a conclusion that amorphous $\mathrm{C}$ is present in the coatings and appendages.

\section{Carbon isotope composition in C-rich particles}

The isotopic composition of carbon was studied (1) in a sample containing abundant quartz grains with dark coatings and black appendages (K191121), (2) in samples of crystalline-derived impact breccia (K13737, K183830), and (3) in magnetic particles separated from the inside-crater crystalline-derived impact breccia (K183984M1; Table 2). For comparison, we determined the isotopic composition of carbon in samples K31/7-4 from Dictyonema shale (Table 2) and $\mathrm{K} 31 / 60$ from the Ordovician limestone. 

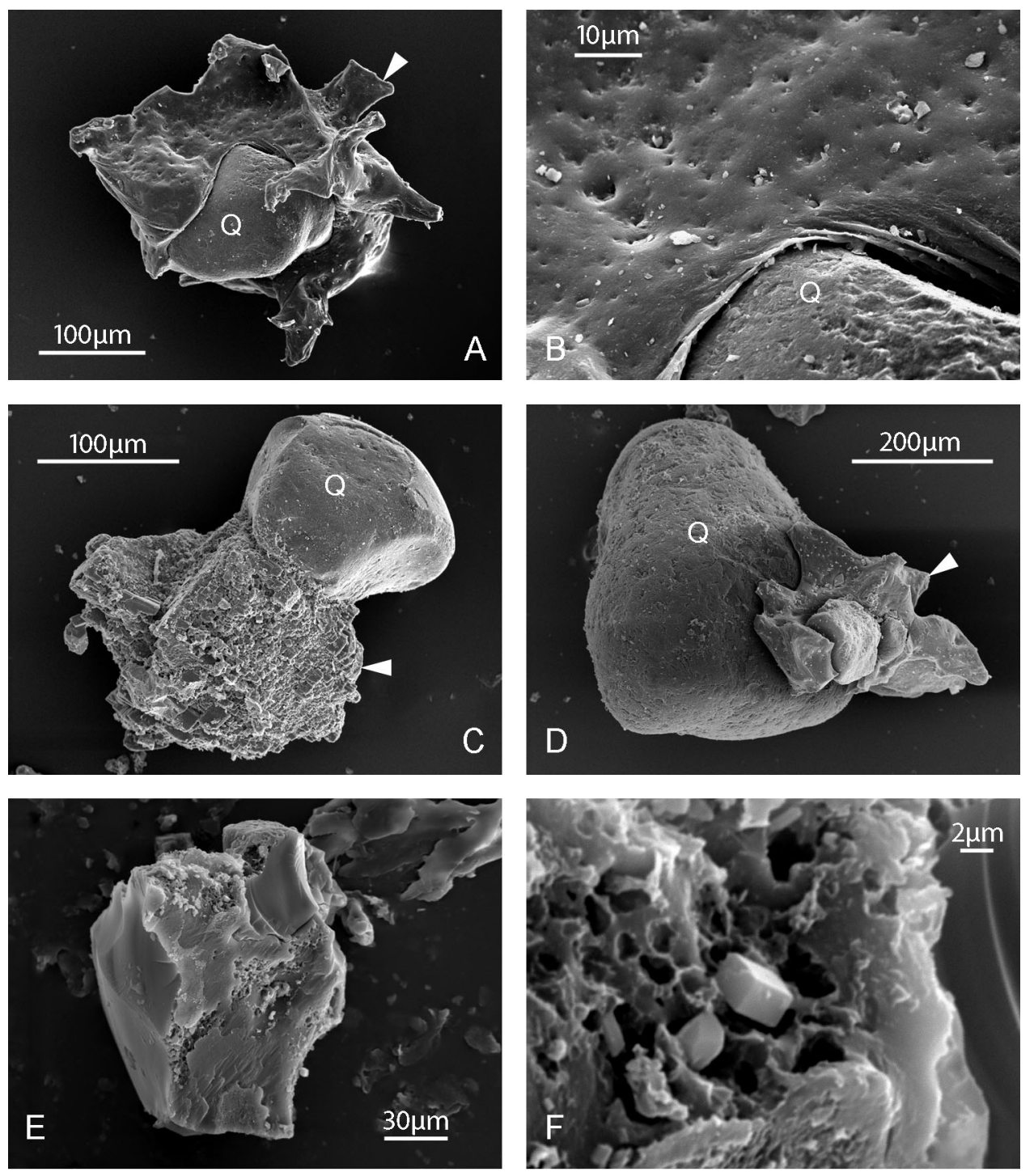

Fig. 13. SEM microphotographs of C-rich coatings and appendages. (A) Quartz grain (Q) surrounded by an intricate C-rich coating (arrow). (B) Detail of (A) with higher magnification showing surface texture with pits. (C) Quartz grain (Q) with a porous C-rich appendage (arrow). (D) Quartz grain (Q) with a C-rich appendage (arrow). (E) C-rich chip, survived after solution. (F) Detail of E with higher magnification showing the porous structure of the material and an authigenic feldspar crystal in a vug. (A)-(C) Sample K140682; (D)-(F) sample K191121. 
Table 2. Non-carbonate carbon isotope data from Kärdla ejecta, impact breccias, and Dictyonema shale. Analyses were carried out in the isotope laboratory of the Geological Survey of Finland, Espoo

\begin{tabular}{|c|c|c|c|c|}
\hline Sample & Sample type & $\begin{array}{c}\delta^{13} \mathrm{X} \\
\text { VPDB } \\
\% \text { \% }\end{array}$ & $\begin{array}{c}\mathrm{C} \text { content, } \\
\%\end{array}$ & $\begin{array}{l}\text { Sample } \\
\text { size, } \\
\mu \mathrm{mol}\end{array}$ \\
\hline K191121 & Ejecta layer, calcite-cemented sandstone & -29.40 & 0.17 & 63.4 \\
\hline K191121-01 & $\begin{array}{l}\text { Quartz grains in the ejecta layer, sur- } \\
\text { rounded by a dark rim }\end{array}$ & -27.30 & 0.31 & 1.7 \\
\hline K191121-02 & $\begin{array}{l}\text { Quartz grains in the ejecta layer, } \\
\text { surrounded by a dark rim }\end{array}$ & -27.00 & 0.37 & 1.7 \\
\hline K13737 & $\begin{array}{l}\text { Crystalline rock-derived impact breccia, } \\
\text { PDF-quartz }\end{array}$ & -27.30 & 0.01 & 2.5 \\
\hline K183830 & $\begin{array}{l}\text { Crystalline rock-derived impact breccia, } \\
\text { PDF-quartz }\end{array}$ & -28.35 & 0.05 & 16.7 \\
\hline K183984M1 & $\begin{array}{l}\text { Crystalline rock-derived magnetic particles } \\
\text { in impact breccia }\end{array}$ & -25.70 & 0.58 & 2.5 \\
\hline $\mathrm{K} 31 / 7-4$ & Reference sample: Dictyonema shale & -29.88 & 7.73 & 346 \\
\hline
\end{tabular}

The $\delta^{13} \mathrm{C}$ and $\delta^{18} \mathrm{O}$ values for limestone sample $\mathrm{K} 31 / 60$ containing $94 \%$ calcite are $-0.36 \%$ and $-4.14 \%$, respectively (Vienna PDB, VPDB). These values are similar to those determined earlier for Ordovician sedimentary carbonates in Estonia (Kaljo et al. 2004). The ejecta layer (core K19, depth $112.1 \mathrm{~m}$, sample $\mathrm{K} 191121)$ contains $24 \%$ calcite with $\delta^{13} \mathrm{C}$ and $\delta^{18} \mathrm{O}$ of $-5.58 \%$ and $-8.98 \%$, respectively, which are lower than the values for well-preserved Ordovician limestones (Martma 2005). The isotopic signatures of the carbonate from sample K191121 are typical of diagenetically formed carbonates and therefore concord with the mode of occurrence of the sampled carbonate, interpreted above as diagenetic. The $\delta^{13} \mathrm{C}$ values of the $\mathrm{C}$-rich particles of the ejecta and impact breccia range from $-25.7 \%$ to $-29.4 \%$. The respective values for the groundmass of the inside-crater crystalline-derived breccia matrix range from $-27.30 \%$ to $-28.35 \%$, and is $-25.70 \%$ for the magnetic particles. All these values are close to the $\delta^{13} \mathrm{C}$ value of Dictyonema shale $(-29.9 \%$; Table 2$)$ and fall into the range for meteorites (from $-30 \%$ to $+10 \%$; Deines 1989 ).

\section{DISCUSSION AND CONCLUSIONS}

A specific sandy layer was formed in the ejecta blanket around the Kärdla crater. It is mostly composed of disintegrated Cambrian Ordovician sandy material, a minor admixture of the other target lithologies (rare fragments of Ordovician carbonate rocks, Lower Ordovician phosphate shell debris, and organic-rich Dictyonema shale), and Precambrian crystalline rocks. The sandy ejecta is either of primary (deposited from the impact-induced debris flow and/or impact plume) 
or secondary (eroded and redeposited from the primary ejecta blanket or rim wall) origin (Puura \& Suuroja 1992; Ainsaar et al. 2002). It contains quartz and other mineral grains with shock metamorphic features - PDFs, PFs, and crack systems.

The presence of quartz grains with PDFs in the ejecta blanket suggests that it contains strongly impact-influenced material among the less impact-influenced particles. The PDF orientation in the within-crater breccia implies shock pressures of 10-35 GPa (Puura et al. 2004). Orientations of PDFs in quartz from the ejecta are more variable, hinting at a somewhat lower maximal shock pressure of 10-25 GPa (using criteria from Langenhorst \& Deutsch 1994; Grieve et al. 1996; French 1998). In Estonia, the association of PDF-quartz with grains with PFs, and milky, low-crystallinity, and heavily cracked quartz grains in sandstones have been found until now only in the ejecta of the Kärdla crater. We assume that all the members of this association are formed due to the impact. The proportion of impact-influenced grains in the ejecta reaches $10-20 \%$, suggesting that at least $1 / 5-1 / 10$ of the ejecta originates from the interior of the high-pressure (core) zone of the impact. However, the major part (80-90\%) of sand shows no shock features. It may be due to the irregular occurrence of shock effects in the OrdovicianCambrian sandy suite or due to the mixing with the Cambrian-Ordovician material derived from the low-pressure marginal zones of the impact. In both cases, the formation of the sandy ejecta layer with generally uniform lithology at a distance of 5-7 km from the crater centre shows an essential selective transport and deposition of the particular sandy mass in the generally chaotic process of impact. Mixing of different lithologies of the pre-impact Ordovician and Cambrian layers suggests high turbulence during the transport. Moreover, a minor admixture of rock fragments from the covering Ordovician limestones and underlying crystalline basement suggests the simultaneous transport of all the impact-crashed lithologies of the target, and, at the same time, principal separation of lithologically different flows.

Specific C-rich material is found in the sandy ejecta, forming drops, hollow bubbles, appendages or worm-like branches, and intricate particles. The C-rich particles occur together with the PDF-quartz in the ejected material only, while they are not registered in the crater interior. The C-rich coatings and particles were previously unknown in the Estonian bedrock. Lately found at Kärdla, they remain insufficiently studied as yet. Carbon in these particles is chemically inert and structurally amorphous. The isotopic compositions (the $\delta^{13} \mathrm{C}$ values $-25.7 \%$ o to $-29.4 \%$, see Table 2) of C-rich coatings, non-carbonate carbon from the breccias, and magnetic particles from the crater interior are close to each other and similar to that of carbon in Dictyonema shale $(-29.9 \%$, Table 2$)$. Because some of such C-rich formations surround quartz grains with PDFs and are often covered with apatite coatings, we assume that this kind of non-carbonate carbon formed during the impact, possibly in the way of condensation of elemental carbon from the vapour plume of low oxygen fugassity finally accumulating on and in fine materials. The sand grains with C-coatings deposited later in the ejecta layer. Their composition does not resemble any bituminous matter rich in $\mathrm{H}$, neither does it resemble any 
crystalline phases like graphite or others. In the succession of mineral formation, the $\mathrm{C}$-rich particles preceded apatite coatings without and with fine-grained pyrite impregnation and the late-impact diagenetic carbonate cement (calcite with dolomite admixture), which covered all these structures.

The organic-rich layers of Dictyonema shale are the most plausible sources of reduced pure carbon in the ejecta and breccia. According to Deines (1989), the $\delta^{13} \mathrm{C}$ values in stony and iron meteorites range from $-30 \%$ to $+10 \%$, and the average values for the groups are around $-14 \%$ and $-11 \%$, respectively. Therefore, a meteoritic source for carbon cannot be completely excluded by these data. However, it would be a remarkable coincidence to find exactly the same $\delta^{13} \mathrm{C}$ value in meteoritic carbon as in local country rocks. In addition, the samples with carbon-rich appendages, drops, and hook-shaped forms contain clasts and grains of Dictyonema shale. Sample K140682 is especially rich in Dictyonema shale particles (Table 1), containing also relatively abundant C-rich forms. Under such circumstances, the mobilization from Dictyonema shale, transport and redeposition of carbon on and in the fine materials of impact breccias obtain outlines of a very short-term and short-distance process that runs within the highly turbulent impact plume. It is notable that the carbon isotope data $(-0.36 \%$ and $-5.58 \%$, see above) exclude carbonate carbon from the $20 \mathrm{~m}$ thick limestone layers as the source for the reduced carbon present in the impact breccias and coated quartz grains in the ejecta layers. Possibly, carbon dioxide forming due to the decarbonization of carbonate rocks during impact is chemically essentially different from the unoxidized carbon of Dictyonema shale or meteorites.

The apatite coatings, covering beside quartz and phosphate debris also C-rich particles and often containing tiny pyrite crystals, were formed in the sandy ejecta blanket during the diagenetic stage. Such apatite coatings have not been found elsewhere in Estonia. Phosphate shell fragments, however, are sometimes covered with transparent rims, often with clear crystallographic surfaces of apatite (Kleesment \& Mägi 1975). These coverings are different from typical coatings of Kärdla ejecta, therefore we suppose the influence of late- or post-impact processes on the formation of apatite coatings found in the ejecta layer.

Carbonate cementation probably took place during late diagenesis. Observations under microscope show that, partially, the formation of apatite coatings might be coeval with the beginning of carbonate cementation. Diagenetic carbonate minerals embedded different particles, including coated, PDF- and PF-bearing, and cracked grains, and also C-rich particles. Tiny crystals of authigenic minerals (feldspars) in hollows of C-rich particles were obviously formed before the cementation and lithification of the ejecta layer.

In the crater interior, the syn- or early post-impact formation of orthoclasetype potassium-feldspar replacing microcline and plagioclase in the allochthonous and autochthonous breccias of the crater interior was the earliest process in the succession of impact-induced authigenic mineralization (Puura et al. 2000a, 2004; Versh et al. 2005). The following phases of early to late post-impact mineralization forming hydrothermal chlorite, dolomite, and calcite occurred in the breccias of 
the crater interior (Kirsimäe et al. 2002). Versh et al. (2005), and Jõeleht et al. (2005) developed a hydrothermal model of post-impact cooling of the interior of the Kärdla crater, with an area of infiltration (cool area) along the rim wall and outside it, and a discharge of hot fluids in the central part. However, it does not firmly follow from the presented model that the hydrothermal system in the crater interior could act as a specific heat and hot fluid source for the mineralization in the area $2-4 \mathrm{~km}$ farther from the crater.

It is possible that specific conditions for diagenesis occurred in the impactdeposited mixed sediments in an atoll-like setting within the shallow sea where carbonate deposition dominated. The possible triggers of such conditions were atoll-like bottom topography of the crater structure in the shallow sea, particular chemical signatures of the immature, impact-influenced debris material on the shallow sea bottom and crater rim area, and minor, but still possible influence of the hydrothermal system active in the crater interior. In the assemblage of diagenetic mineralization, in addition to calcite precipitation also dolomitization has been observed (Kleesment et al. 1987). Before carbonate formation, phosphate coatings were precipitated on quartz, shell debris, and other grains. Altogether, these processes could have lasted millions of years as estimated from the input of detrital material into the post-impact carbonate sediments (Ainsaar et al. 2002) in the area around the crater site.

The mineral association of apatite, carbonate, and pyrite is known to form at the same stage of black-shale diagenesis during sulphate reduction (Lev et al. 1999), and also by strongly acidic magmatic-hydrothermal fluids induced by phosphatebearing minerals (Bajnóczi et al. 2004). However, due to the abundant carbonate debris in the sequence, formation of highly acidic fluids is improbable.

The results of our investigation specify the history of mineralization during the crater-forming and subsequent processes. The studied ejecta material forms a unique impact-accumulated, mixed but yet lithologically uniform body of predominantly sand-size material. Its lower part is of a kind of avalanche-type deposition from debris flow and/or plume environments. In such environments, PDF-rich and other impact-influenced mineral grains as well as C-rich particles deposited. The upper part of the sandy unit is a probable product of the redeposition of the same material in marine conditions, with an admixture of some amount of debris derived from the erosion of the crater rim. The apatite coatings formed during the late post-impact to early diagenetic mineralization processes, and carbonate cement at later stages of diagenesis.

\section{ACKNOWLEDGEMENTS}

Tom Flodén and Marianne Ahlbom of the Department of Geology and Geochemistry, Stockholm University, contributed to ESEM investigations, when the C-rich particles were first recognized. Valdek Mikli performed SEM microscopy and EDS chemical analyses of apatite coatings. Gennadi Baranov (IG TUT) made 
photographs. Kalle Kirsimäe (IG UT) helped to elucidate the composition of C-rich particles. Critical reading and numerous suggestions by the referees Jüri Plado and Maurits Lindström significantly improved the manuscript. The authors are grateful to all of them. Financial support from the Estonian Ministry of Education (project No. 02332088c02) and Estonian Science Foundation (grants Nos 5500, 5726, and 5817) is acknowledged.

\section{REFERENCES}

Ainsaar, L., Suuroja, K. \& Semidor, M. 2002. Long-term effect of the Kärdla crater (Hiiumaa, Estonia) on Late Ordovican carbonate sedimentation. Deep-Sea Res., 49, 1145-1155.

Bajnóczi, B., Seres-Hartai, E. \& Nagy, G. 2004. Phosphate-bearing minerals in the advanced argillitic alternation zones of high-sulphidation type ore deposits in the Carpatho-Pannonian region. Acta Miner.-Petr. Szeged, 45, 81-92.

Deines, P. 1989. Isotope variations in carbonatites. In Carbonatites, Genesis and Evolution (Bell, K., ed.), pp. 301-359. Hyman, London.

Deutsch, A., Masaitis, L. V., Langenhorst, F. \& Grieve, R. A. F. 2000. Popigai, Siberia - well preserved giant impact structure, national treasury, and world's geological heritage. Episodes, 23, 3-21.

French, B. M. 1998. Trace of Catastrophe. A Handbook of Shock-Metamorphic Effects in Terrestrial Meteorite Impact Structures. LPI Contribution 954. Lunar Planet Institute, Houston.

French, B. M., Koeberl, C., Gilmour, I., Shirey, S. B., Dons, J. A. \& Naterstad, J. 1997. The Gardnos impact structure, Norway: petrology and geochemistry of target rocks and impactites. Geochim. Cosmochim. Acta, 61, 873-904.

Grieve, R. F., Langenhorst, F. \& Stöffler, D. 1996. Shock metamorphism of quartz in nature and experiment: II. Significance in geoscience. Meteor. Planet. Sci., 31, 6-35.

Hodel, K. L., Reimnitz, E. \& Barnes, P. W. 1988. Microtextures of quartz grains from modern terrestrial and subaqueous environments, North slope of Alaska. J. Sedim. Res., 58, 24-31.

Isbell, J. L., Askin, R. A. \& Retallack, G. J. 1999. Search for evidence of impact at the PermianTriassic boundary in Antarctica and Australia: comment and replay. Geology, 27, 859-860.

Jõeleht, A., Kirsimäe, K., Plado, J., Versh, E. \& Ivanov, B. 2005. Cooling of the Kärdla impact crater: II. Impact and geothermal modeling. Meteor. Planet. Sci., 40, 21-33.

Kaljo, D., Hints, L., Martma, T., Nõlvak, J. \& Oraspõld, A. 2004. Late Ordovician carbon isotope trend in Estonia, its significance in stratigraphy and environmental analysis. Paleogeogr. Palaeoclimatol. Palaeoecol., 185, 164-185.

Kirsimäe, K., Suuroja, S., Kirs, J., Kärki, A., Polikarpus, M., Puura, V. \& Suuroja, K. 2002. Hornblende alternation and fluid inclusions in the Kärdla impact crater, Estonia: evidence for impactinduced hydrothermal activity. Meteor. Planet. Sci., 37, 449-457.

Kleesment, A. 1998. Authigenic overgrowths of detrital feldspar grains in the Devonian sequence of the East Baltic. Proc. Estonian Acad. Sci. Geol., 47, 229-241.

Kleesment, A. \& Mägi, S. 1975. On the lithology and mineralogy of terrigenous glauconite deposits in Ceratopyge and Latorpian stages of Estonian structural-facial zones. Eesti NSV Tead. Akad. Toim. Geol., 24, 131-139 (in Russian).

Kleesment, A.-L., Pirrus, E., Suuroja, K. \& Tiirmaa, R. 1987. Geology of the north-eastern outer slope of the mound of the Kärdla buried crater. Eesti NSV Tead. Akad. Toim. Geol., 36, 131-139 (in Russian).

Koeberl, C., Reimold, W. U., Kracher, A., Träxler, B., Vormaier, A. \& Körner, W. 1996. Mineralogical, petrographical, and geochemical studies of drill core samples from the Manson impact structure, Iowa. In The Manson Impact Structure, Iowa: Anatomy of an Impact Crater, Boulder, Colorado (Koeberl, C. \& Anderson, R. R., eds). Geol. Soc. Am. Spec. Pap., 302, 145-219. 
Konsa, M. 1989. Typomorphic features of quartz in the crystalline basement and basal layers of sedimentary rocks of Estonia. Eesti NSV Tead. Akad. Toim. Geol., 38, 1-9 (in Russian).

Konsa, M., Kleesment, A. \& Puura, V. 2000. Alteration of zircon and garnet due to low-pressure shock at the Kärdla crater, Estonia. Proc. Estonian Acad. Sci. Geol., 49, 251-266.

Krinsley, D. \& Doornkamp, J. 1973. Atlas of Quartz Sand Surface Textures. Cambridge University Press.

Langenhorst, F. \& Deutsch, A. 1994. Shock experiments on pre-heated $\alpha$ - and $\beta$-quartz: I. Optical and density data. Earth Planet. Sci. Lett., 125, 407-420.

Langenhorst, F., Safranovsky, G. I., Masaitis, V. L. \& Koivisto, M. 1999. Discovery of impact diamonds in a Fennoscandian crater and evidence for their genesis by solid-state transformation. Geology, 27, 747-750.

Lev, S. M., McLennan, S. M. \& Hanson, G. N. 1999. Mineralogic controls on REE mobility during black-shale diagenesis. J. Sedim. Res., 69, 1071-1082.

Mahaney, W. C. 2002. Atlas of Sand Grain Surface Textures and Applications. Oxford University Press.

Martma, T. 2005. Ordovician carbon isotopes. In Mehikoorma (421) Drill Core (Põldvere, A., ed.). Estonian Geol. Sections, 6, 25-27.

McCarville, P. \& Crossey, L. J. 1996. Post-impact hydrothermal alternation of the Manson impact structure. In The Manson Impact Structure, Iowa: Anatomy of an Impact Crater, Boulder, Colorado (Koeberl, C. \& Anderson, R. R., eds). Geol. Soc. Am. Spec. Pap., 302, 347-376.

Puura, V. \& Suuroja, K. 1992. Ordovician impact crater at Kärdla, Hiiumaa Island, Estonia. Tectonophysics, 216, 143-156.

Puura, V., Suuroja, K. \& Kleesment, A. 1997. External impact-related clastic sediments, Kärdla Crater, NW Estonia. In Impact and Extraterrestrial Spherules: New Tools for Global Correlation (Raukas, A., ed.), pp. 43-44. Institute of Geology, Tallinn.

Puura, V., Kärki, A., Kirs, J., Kirsimäe, K., Kleesment, A., Konsa, M., Niin, M., Suuroja, K. \& Suuroja, S. 2000a. Impact-induced replacement of plagioclase by K-feldspar in granitoids and amphibolites at the Kärdla crater, Estonia. In Impacts and the Early Earth (Gilmour, I. \& Koeberl, C., eds), pp. 417-445. Springer-Verlag, Berlin.

Puura, V., Konsa, M., Kleesment, A., Kirs, J., Kirsimäe, K. \& Suuroja, K. 2000b. Carbon-rich and magnetic spherules and particles from Kärdla ejecta, Estonia. In Meteoritic Impacts in Precambrian Shields. Programme and Abstracts (Plado, J. \& Pesonen, J., eds), p. 87. Geological Survey of Finland, University of Helsinki; Espoo.

Puura, V., Kirs, J., Konsa, M., Kleesment, A., Plado, J., Preeden, U. \& Suuroja, K. 2002. Kärdla Crater: the transient and present structure, localization of shocked minerals, estolites, carboncoated fused quartz, and K-metasomatites. In 8th Workshop of the European Science Foundation Program IMPACT "Impact Tectonism”, Mora, Sweden, p. 53.

Puura, V., Huber, H., Kirs, J., Kärki, A., Suuroja, K., Kirsimäe, K., Kivisilla, J., Kleesment, A., Konsa, M., Preeden, U., Suuroja, S. \& Koeberl, C. 2004. Geology, petrography, shock petrography, and geochemistry of impactites and target rocks from the Kärdla crater, Estonia. Meteor. Planet. Sci., 39, 425-451.

Reimold, W. U., Koeberl, C. \& Bishop, J. 1994. Roter Kamm impact crater, Namibia: geochemistry of basement rocks and breccias. Geochim. Cosmochim. Acta, 58, 2689-2710.

Retallack, G. I., Seyedolali, A., Krull, E. S., Holser, W. T., Ambers, C. P. \& Kyte, F. T. 1998. Search for evidence of impact at the Permian-Triassic boundary in Antarctica and Australia. Geology, 26, 979-982.

Stöffler, D. \& Langenhorst, F. 1994. Shock metamorphism of quartz in nature and experiment: I. Basic observation and theory. Meteoritics, 29, 155-181.

Suuroja, K., Suuroja, S., All, T. \& Floden, T. 2002. Kärdla (Hiiumaa Island, Estonia) - the buried and well-preserved Ordovician marine impact structure. Deep-Sea Res., 49,1121-1144.

Versh, E., Kirsimäe, K., Jõeleht, A. \& Plado, J. 2005. Cooling of the Kärdla impact crater: I. The mineral paragenetic sequence observation. Meteor. Planet. Sci., 40, 3-19. 


\title{
Meteoriidiplahvatuse mõjul ja diageneesi vältel tekkinud mineraalterade muutused Kärdla kraatrit ümbritsevas liivakas väljapaiskelasundis
}

\author{
Anne Kleesment, Mare Konsa, Väino Puura, Juha Karhu, Ulla Preeden \\ ja Toivo Kallaste
}

Viies puursüdamikus on uuritud Kärdla kraatrit ümbritsevat liivakat väljapaiskelasundit, mis sisaldab plahvatuse tagajärjel tekkinud mineraalteradega seotud ilminguid. On määratud lööklaine mõjul tekkinud planaarsete lõhede orientatsioon kvartsiterades. Valdava $\{10 \overline{1} 3\}$ kõrval on määratud suunad $\{10 \overline{1} 1\},\{10 \overline{1} 2\}$ ja $\{22 \overline{4} 1\}$. Selline planaarsete lõhede iseloom viitab rõhkudele 10-25 GPa. Väljapaiskelasundis, 2-5 km kaugusel kraatri vallist, esineb kvartsi ja teiste mineraalterade pinnal keeruliste jätkete ja katetena omapäraseid süsinikurikkaid moodustisi. Röntgenuuringud on näidanud, et tegu on süsiniku amorfse faasiga. Isotoopkoostis osutab süsiniku võimalikule päritolule diktüoneemakildast. Vaadeldavas lasundis on mineraalterad sageli kaetud kollaka läbipaistva, poolläbipaistva või püriiti sisaldava opaakse apatiitse kattega. Apatiitse katte teke toimus diageneesil, eelnedes põhilises osas karbonaatse tsementatsiooni protsessidele. Kirjeldatud süsinikurikkad moodustised ja apatiitsed katted on esmasleiud Eesti aluspõhjast. Apatiitseid katteid pole seni ka üheski teises meteoriidikraatris kirjeldatud. 